\title{
In vitro antioxidant, antimutagenic and antiproliferative activities of collagen hydrolysates of jumbo squid (Dosidicus gigas) byproducts
}

\author{
Guadalupe Miroslava SUÁREZ-JIMÉNEZ ${ }^{1}$, Rosario Maribel ROBLES-SÁNCHES ${ }^{1}$, Glória YÉPIZ-PLASCENCIA², \\ Armando BURGOS-HERNÁNDEZ ${ }^{1}$, Josafat Marina EZQUERRA-BRAUER ${ }^{1 *}$
}

\begin{abstract}
Hydrolysates from two different jumbo squid byproducts (fins and arms), produced by trypsin and protease type XIV were compared on the basis of their antioxidant (DPPH and ABTS radical scavenging assays), antimutagenic (Ames test) and antiproliferative (Transformation cell proliferation in M12.C3F6 murine cells) activities. Jumbo squid arms had higher content of collagen than fins, and their hydrolysates had the highest antioxidant activity. Also, jumbo squid arm-derived collagen hydrolyzed with protease XIV showed the highest antimutagenic activity. The four hydrolysates obtained showed low antiproliferative activity, however they are susceptible for further studies to be applied as food additives.
\end{abstract}

Keywords: jumbo squid by-products; collagen hydrolysates; antioxidant activity; antimutagenic activity; antiproliferative activity.

Practical Application: Utilization of jumbo squid byproducts by preparing bioactive hydrolysates

\section{Introduction}

The interest in finding antioxidants from natural sources has become one of the fastest growing fields of study in food chemistry all over the world in the recent years ( $\mathrm{Lin} \& \mathrm{Li}, 2006$ ), the latter due to their potential of being used for the prevention and treatment of diseases associated to reactive oxygen species (ROS), especially cancer (Je et al., 2005); they are known to be beneficial to human health as they may protect the body against membrane lipids, protein, and DNA damage (Samaranayaka \& Li-Chan, 2011).

Seafood byproducts have been reported as a good source of antioxidant compounds (Je et al., 2005; Jeon et al., 2002), from which squid byproducts are one of the alternative sources of these natural antioxidants. Among squid species, jumbo squid (Dosidicus gigas), in addition to being the largest known cephalopod, presents a high amount of byproducts produced during its processing (skin, fins, arms, and head) (Lin \& Li, 2006), which have collagen as the most prevalent protein (Alemán et al., 2011a; Gildberg et al., 2002). Collagen has a particular molecular structure, which is rich in non-polar amino acids (above 80\%) such as glycine, alanine, valine, and proline, and provides collagen specific properties (Kim \& Mendis, 2006).

The main jumbo squid byproduct studied until now is skin. Skin collagen has been enzymatically hydrolyzed to recover proteins and peptide fractions. The peptides isolated from squid skin collagen hydrolysates have shown numerous beneficial properties such as antihypertensive, antithrombotic, immunomodulatory, antiproliferative, and antioxidative activities (Alemán et al., 2011a; Gómez-Guillén et al., 2011; Kim \& Mendis, 2006). Moreover, it is known that the molecular size, hydrophobicity, and exposition of polar groups of the peptides produced depend on the enzyme used for protein hydrolysis; this also influences their bioactive properties(Kristinsson, 2007).

Based on the available scientific literature, there is scarce information about the functional properties of jumbo squid fins and arms collagen hydrolysates. Furthermore, due to the structural differences between collagen extracted from fins and that from arms (Torres-Arreola et al., 2008), it is possible that these differences may be reflected in the collagen hydrolysates properties.

The aim of this study was to determine and compare the antioxidant, antimutagenic, and antiproliferative activities of two jumbo squid by-products (fins and arms) collagen hydrolysates obtained by digestion with two different proteases, as measured by free radical scavenging activity assays (DPPH and ABTS), Ames test, and MTT assay respectively.

\section{Materials and methods}

\subsection{Materials}

Fifty jumbo squids (D. gigas) were collected from the Sea of Cortez $\left(8.75^{\circ} \mathrm{N} / 112.25^{\circ} \mathrm{W}, 15-18^{\circ} \mathrm{C}\right)$. Squid had a length of $45-50 \mathrm{~cm}$ and weight of 2.5 to $3.0 \mathrm{Kg}$. Immediately after capture, specimens were stored in an iced bed system and transported to the seafood laboratory at the Universidad de Sonora. The time elapsed from capture until beginning of the dissection process was $24 \mathrm{~h}$. Squids were dissected and fins and arms were collected. Trypsin (EC. 3.4.21.4), protease type XIV from Streptomyces griseus, $o$-phthalaldehyde (OPA), 2,2-diphenyl-1-picryhidrazyl 
(DPPH), 6-hydroxy-2,5,7,8-tetramethylchroman-2-carboxylic acid (Trolox), 2,2'-azino-bis-(3-ethylbenzothiazoline-6-sulphonic acid) (ABTS radical) were all purchased from Sigma-Aldrich (St. Louis, MO, USA). All other reagents were of analytical grade.

\subsection{Collagen extraction}

The collagen extraction process was established in preliminaries studies, in order to facilitate the removal of contractile proteins from high muscular regions of jumbo squid by-products (fins and arms). Briefly, minced fins and arms were homogenized with water $(1: 3 \mathrm{w} / \mathrm{v}$ ) using an Ester blender (model BRYL07-ZOO) at high speed for $60 \mathrm{~s}$, centrifuged at $3823 \mathrm{xg}$ using a Hermle Labnet centrifuge (model Z326K, New Jersey, USA) for $1.5 \mathrm{~h}$ at $4^{\circ} \mathrm{C}$. The precipitate was subjected to homogenization with $\mathrm{NaOH} 0.5 \mathrm{~N}(1: 3 \mathrm{w} / \mathrm{v})$ for $1 \mathrm{~h}$ and centrifuged at the same conditions. The precipitate was homogenized with $\mathrm{HCl} 0.5 \mathrm{~N}$ $(1: 3 \mathrm{w} / \mathrm{v})$ and centrifuged at the same conditions. The resulting precipitate was freeze-dried for two days (LABONCO Freeze Dry, Kansas City, MO, USA). About $100 \mathrm{~g}$ of freeze-dried fins and arms were placed in polyethylene-sealed bags and stored at $-80^{\circ} \mathrm{C}$ for further analyses. Collagen content was established by multiplying hydroxyproline content by 21.56 according to Sikorski \& Borderías (1994).

\subsection{Preparation of collagen hydrolysates}

Collagen was dissolved in $100 \mathrm{mM}$ sodium-phosphate buffer pH $8.0(0.4 \mathrm{mg}$ protein $/ \mathrm{mL})$ and enzymatic hydrolysis with trypsin and protease XIV was performed for $30 \mathrm{~min}$ at $37^{\circ} \mathrm{C}$ and $\mathrm{pH} 8.0$ according to Adler-Nissen (1986) with an enzyme-substrate ratio (E/S) of 1:100 (v:v) and 0.2\% (w/w), respectively, for $30 \mathrm{~min}$. The enzymes were inactivated by heating at $100^{\circ} \mathrm{C}$ for $10 \mathrm{~min}$ and the samples centrifuged at $3823 \times g$ for $15 \mathrm{~min}$. Supernatants comprised the hydrolysates were lyophilized and stored at $-80^{\circ} \mathrm{C}$ for further assays. The hydrolysates obtained were further named as follows: hydrolysate obtained from collagen fins with trypsin (HFT), hydrolysate obtained from collagen fins with protease type XIV (HFP), hydrolysate obtained from collagen arms with trypsin (HAT), hydrolysate obtained from collagen arms with protease type XIV (HAP).

\subsection{Degree of hydrolysis (DH)}

DH was defined as the percentage of peptide bonds cleaved, and it was calculated by determining free amino groups by reaction with OPA reagent according to Nielsen et al. (2001) using serine as standard.

\subsection{Molecular weight distribution}

Collagen was analyzed by SDS-PAGE according to Laemmli (1970) using a 5\% stacking gel and a 10\% resolving gel for collagen, whereas the hydrolysates were analyzed by Tricine-SDS-PAGE according to Schägger (2006) with a $4 \%$ stacking gel, a $10 \%$ separating gel and a $16 \%$ resolving gel. Collagen molecular weight (MW) was determined using a broad range molecular weight marker kit (Bio-Rad, CA, USA), whereas hydrolysates
MW was determined using a peptide molecular weight marker kit (Sigma-Aldrich, St. Louis, MO, USA).

\subsection{Amino acid composition}

For determination of amino acid composition, $100 \mathrm{mg}$ samples were subjected to acid hydrolysis with $20 \mathrm{~mL} 6 \mathrm{~N} \mathrm{HCl}$ at $105^{\circ} \mathrm{C}$ for $24 \mathrm{~h}$. The hydrolysate residue was dissolved in $2 \mathrm{~mL}$ of distilled water and filtered using a $0.2 \mu \mathrm{m}$ cellulose acetate syringe filter unit. The resulting solution was analyzed using reverse phase high pressure liquid chromatography (RP-HPLC) (Vazquez-Ortiz et al., 2004).

\subsection{Bioactivity properties}

\section{Antioxidant activity}

ABTS and DPPH scavenging ability assays were performed to study the antioxidant properties of squid fin and arm collagens, and the corresponding hydrolysates, at a concentration of $2.5 \mathrm{mg} / \mathrm{mL}$. The ABTS radical [2,2'-azino-bis-(3-ethylbenzothiazoline6-sulfonic acid)] scavenging assay was carried out according to the method described by Re et al. (1999). ABTS radical stock solution was prepared according to the method and a $20 \mu \mathrm{L}$ aliquot sample was mixed with $980 \mu \mathrm{L}$ of ABTS reagent and left to stand at the dark for $10 \mathrm{~min}$ at $30^{\circ} \mathrm{C}$. Absorbance values were read at $734 \mathrm{~nm}$ using a Varian Cary $50 \mathrm{UV}$-Vis spectrophotometer (Sidney, Australia). Results were expressed as $\%$ of radical scavenging activity (RSA).

DPPH radical scavenging activity was determined according to the method of Burits \& Bucar (2000). Aliquots of collagens and hydrolysates, at a concentration of $2.5 \mathrm{mg} / \mathrm{mL}$, were transferred to test tubes and dissolved in $1 \mathrm{~mL}$ of ethanol, followed by the addition of $4 \mathrm{~mL}$ of $0.004 \%(\mathrm{w} / \mathrm{v})$ of DPPH solution in methanol. The tubes were incubated at room temperature for $30 \mathrm{~min}$ and the absorbance was read at $517 \mathrm{~nm}$. The radical scavenging activity was calculated as followed (Equation 1):

$\operatorname{RSA}(\%)=($ A control - A sample $) / A$ control $x 100$

\section{Antimutagenic activity}

The Ames test was used to evaluate the antimutagenic activity of the hydrolysates. The hydrolysates were dissolved in deionized water and tested with Salmonella typhimurium strains TA98 and TA100 (100 $\mu \mathrm{l} /$ plate of a fresh overnight culture $)\left(1-2 \times 10^{9}\right.$ cells $\left./ \mathrm{ml}\right)$ with $500 \mu \mathrm{l}$ of an exogenous metabolic activation system (S9 mix) (Aroclor 1254-induced, Sprague-Dawley male rat liver in $0.154 \mathrm{M}$ $\mathrm{KCl}$ solution). Aflatoxin $\mathrm{B}_{1}\left(\mathrm{AFB}_{1}\right)$ was used as a control mutagen. Metabolic Activation System S9 mix, purchased from (Molecular Toxicology, Inc.; Annapolis, MD, U.S.) was used to bioactivate the $\mathrm{AFB}_{1}$. All assays were performed in triplicate.

The concentrations of hydrolysates in the test samples used were 50 and $5 \mathrm{mg} / \mathrm{ml}$ of which, $100 \mu \mathrm{l}$ of each were used in the assay, resulting in final concentrations of 5 and $0.5 \mathrm{mg} / \mathrm{plate}$. The plate for negative control contained $100 \mu \mathrm{l}$ of $10 \%$ DMSO without $\mathrm{AFB}_{1}$. The colonies were manually counted after $48 \mathrm{~h}$ of incubation at $37^{\circ} \mathrm{C}$ using a colony counter. The inhibitory effect of hydrolysates (at 5 and $0.5 \mathrm{mg} /$ plate) on the mutagenic 
activity of $500 \mathrm{ng} \mathrm{AFB}_{1}$ /plate were examined using the plate incorporation assay as described by Maron \& Ames (1983). The inhibition rate of mutagenicity (\%) was calculated relative to those in the control group with the mutagen as \% Inhibition = $(1-\mathrm{T} / \mathrm{M}) \times 100$ where $\mathrm{T}$ is the number of revertants per plate in the presence of mutagen and the test sample and $\mathrm{M}$ is the number of revertants per plate in the positive control (mutagen alone).

\section{Antiproliferative activity}

The effect of the different hydrolysates on the proliferation of a transformed cell line was determined using the standard MTT assay (3-(4,5-dimethylthiazol-2-yl)-2,5-diphenyltetrazolium bromide) (Mosmann, 1983). Cell line M12.C3F6 (murine B-cell lymphoma) was kindly provided by Dr. Emil R. Unanue (Department of Pathology and Immunology, Washington University at St. Louis, MO, U.S.). Cell lines were cultured in Dulbecco's modified Eagle's medium (DMEM) supplemented with $5 \%$ heat inactivated fetal calf serum and grown at $37^{\circ} \mathrm{C}$ in an atmosphere of $5 \% \mathrm{CO}_{2}$. Briefly, 10,000 cells $(50 \mu \mathrm{L})$ were placed in each well of a flat $96-$ well plate. After $12 \mathrm{~h}$ of incubation in an atmosphere of $5 \% \mathrm{CO}_{2}$ at $37^{\circ} \mathrm{C}$, cell cultures were then incubated with $100 \mu \mathrm{L}$ of medium containing $100 \mu \mathrm{g} / \mathrm{mL}$ of the hydrolysates and further incubated for $48 \mathrm{~h}$. Control cell cultures were incubated with DMSO (final concentrations of DMSO 0.06-0.5\% (v/v)). Control cell cultures did not show any evidence of cell damage. Prior to last $4 \mathrm{~h}$ of the cell culture, $10 \mu \mathrm{L}$ of MTT stock solution $(5 \mathrm{mg} / \mathrm{mL})$ were added to each well. Formazan crystals formed were dissolved with acidic isopropanol and cell viability was determined using an ELISA plate reader (Benchmark Microplate Reader, Bio-Rad, Hercules, CA, U.S.) at a test wavelength of $570 \mathrm{~nm}$ and a reference wavelength of $630 \mathrm{~nm}$. Cell viability (\%) was calculated as: Cell viability $(\%)=[($ sample absorbance with cells-sample absorbance without cells)/(control absorbance with cells-control absorbance without cells) $] \times 100$.

\subsection{Statistical analysis}

A $2 \times 2$ factorial in randomized complete block design was used, where the factor one was the type of byproduct (fins and arms), and the second the enzyme system used (trypsin and protease XIV). Statistical tests were performed using the SPSS ${ }^{\circ}$ computer program (SPSS Statistical Software, Inc., Chicago, IL, USA). Data were expressed as mean \pm standard deviation of three determinations. Tukeyss test was used to determine the level of significance at $p<0.05$.

\section{Results and discussion}

\subsection{Collagen extraction}

The method used for collagen extraction allowed the separation of several types of protein. The content of proline, hydroxyproline, and collagen extracted from arms $(3.96 \pm 0.018,0.66 \pm 0.025$, and $14.23 \pm 0.59 \mathrm{~g} / \mathrm{Kg}$ tissue, respectively) was statistically higher $(p<0.05)$ than those from fins $(2.19 \pm 0.053,0.31 \pm 0.015$, and $6.68 \pm 0.3 \mathrm{~g} / \mathrm{Kg}$ tissue, respectively). These values are lower to those reported for other squid species (3-18 g/100 g) (Morales et al., 2000; Sikorski \& Borderias, 1994; Torres-Arreola et al., 2008); this might be due to several factors such as size and sexual maturity of organisms, which can influence connective tissue and collagen content (Ando et al., 2006; Sikorski \& Borderias, 1994). It is noteworthy that the purpose of this research was to characterize collagen and its enzymatic hydrolysates; therefore, the extraction method used was considered appropriate.

\subsection{Degree of hydrolysis (DH)}

The DH\% obtained was higher with protease XIV using collagen from fins $(28.1 \pm 2.2)$ and arms $(22.3 \pm 3.3)$, compared with hydrolysates obtained with trypsin using collagen from fins $(24 \pm 2.8)$ and arms (15.4 \pm 2.2$)$. Although the bioactivity of proteins may be increased by hydrolysis with specific enzymes, producing peptides that might be more chemically interactive, there is evidence that DH affects the peptide size and therefore, the functional and biological properties of the resulting hydrolysates, and is worth mentioning that high values of $\mathrm{DH}$ are not desirable since free amino acid and very small peptides cannot act as an antioxidant. Kong \& Xiong (2006) reported that, if the hydrolysis of zein protein carried out using alcalase became too extensive, the hydrolysate could reduce the peptide's ability to act as an antioxidant. You et al. (2009) observed an increase of the proportion of peptides with MW below $500 \mathrm{Da}$ as $\mathrm{DH}$ values increased in loach protein hydrolysates.

\subsection{Characterization of collagen hydrolysates}

The type of protease used to hydrolyze collagen into peptides affects peptide parameters such as size, amount produced, and amino acid sequence, which influences their biological activity (Harnedy \& FitzGerald, 2012); therefore, it is necessary to evaluate the differences between the hydrolysates obtained with each kind of protease, trypsin, and protease type XIV.

Molecular weight distribution of squid collagen hydrolysates obtained with the different enzymes was determined by SDS-PAGE. Before hydrolysis, the characteristic band for collagen $\alpha$-chain was observed $(97 \mathrm{KDa})$. The presence of a $45 \mathrm{KDa}$ fraction (Figure 1a) could be due to the presence of elastin, another stromal protein that is commonly found in collagen isolates due to the interlinking between these two proteins (Foster, 2013). After $1 \mathrm{~h}$ of hydrolysis with each enzyme, collagen extracted from fins and arms showed several bands with lower MW than the original sample (Figure 1b). Enzymatic hydrolysis produced peptides with MW ranging from $16 \mathrm{KDa}$ to lower than $2.5 \mathrm{KDa}$ (Figure $1 \mathrm{~b}$ ). The size of the peptides produced was very similar; therefore it was not possible to observe well-defined bands. Then, hydrolysis with both proteases used in this study, produces peptides with low MW, which could contribute to enhance different activities such antioxidant and antimutagenic activities (Malaypally et al., 2014).

The amino acid composition of peptides strongly influences its biological activity (Sarmadi \& Ismail, 2010). Hydrolysis of collagen from fins and arms with trypsin and protease XIV changed the percentage of most amino acids; however, there is not an appreciable difference among hydrolysates (Table 1). All obtained hydrolysates were rich in glycine, arginine, leucine, glutamic acid, aspartic acid, and proline. These amino acids have been reported to contribute to the free radicals scavenging (Kim \& Mendis, 2006). 


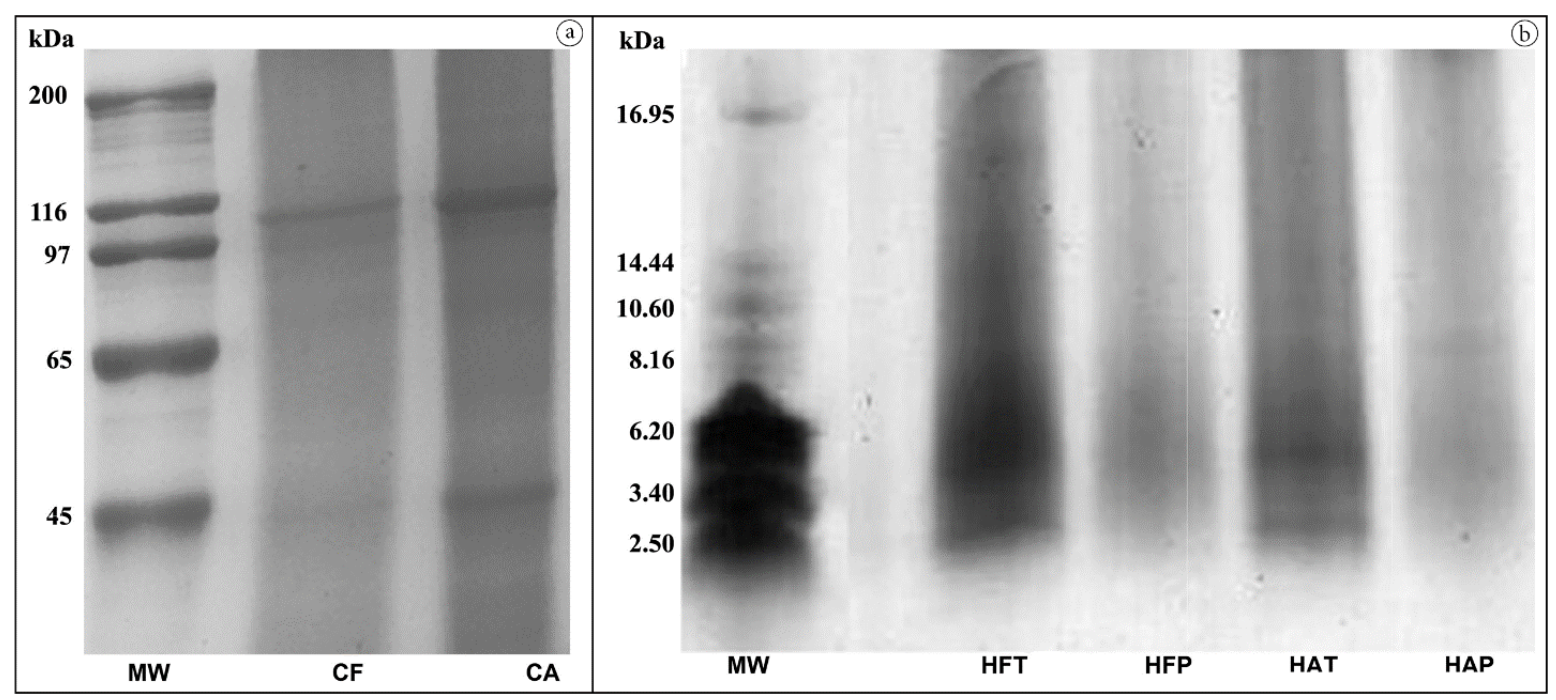

Figure 1. Electroforetic profile (SDS-PAGE) of collagen extracted from jumbo squid and its hydrolysates. (a) Collagen extracted from fins (CF) and arms (CA). MW: high molecular weight marker. (b) MW: peptide MW marker; HFT: collagen fins hydrolysed with trypsin, HFP: collagen fins hydrolysed with protease type XIV, HAT: collagen arms hydrolysed with trypsin, HAP: collagen arms hydrolysed with protease type XIV.

Table 1. Amino acid composition of squid by-products collagen and its hydrolysates obtained by trypsin and protease type XIV 1 ) (g/100 g protein).

\begin{tabular}{|c|c|c|c|c|c|c|}
\hline Amino acid & $\mathrm{CF}$ & HFT & HFP & $\mathrm{CA}$ & HAT & HAP \\
\hline Asp & 32.74 & 23.45 & 15.08 & 38.44 & 8.43 & 18.82 \\
\hline Glu & 57.74 & 38.55 & 25.24 & 69.65 & 12.06 & 31.50 \\
\hline Lys & 34.59 & 18.94 & 10.77 & 40.82 & 11.27 & 16.21 \\
\hline Arg & 47.10 & 26.26 & 16.48 & 57.35 & 14.08 & 18.40 \\
\hline His & 11.72 & 2.98 & 2.67 & 14.02 & 2.02 & 3.89 \\
\hline Ser & 1.52 & 8.50 & 5.92 & 2.81 & 0.44 & 1.87 \\
\hline Thr & 5.86 & 9.21 & 5.30 & 8.93 & 0.00 & 4.25 \\
\hline Met & 10.73 & 5.91 & 3.61 & 12.69 & 2.81 & 5.10 \\
\hline Gly & 44.58 & 29.47 & 22.65 & 52.40 & 12.60 & 20.21 \\
\hline Ala & 28.10 & 5.88 & 2.69 & 33.18 & 2.33 & 3.75 \\
\hline Val & 19.94 & 7.39 & 5.49 & 22.95 & 5.14 & 7.68 \\
\hline Ile & 19.05 & 8.71 & 4.47 & 22.03 & 4.78 & 6.73 \\
\hline Leu & 30.47 & 17.05 & 10.46 & 37.03 & 9.33 & 13.67 \\
\hline Tyr & 7.52 & 15.02 & 10.05 & 10.44 & 7.77 & 11.30 \\
\hline Phe & 16.09 & 7.25 & 3.59 & 8.02 & 3.92 & 5.72 \\
\hline Pro & 58.36 & 16.26 & 12.29 & 64.38 & 15.80 & 12.34 \\
\hline Hyp & 8.29 & 7.77 & 6.09 & 10.65 & 7.83 & nd \\
\hline - Charged & 90.48 & 62.00 & 40.32 & 108.09 & 20.49 & 50.32 \\
\hline+ Charged & 93.41 & 48.18 & 29.92 & 112.19 & 27.37 & 38.50 \\
\hline Polar without charge & 62.69 & 53.09 & 37.48 & 76.83 & 15.85 & 31.43 \\
\hline No Polar & 97.56 & 39.03 & 23.11 & 115.19 & 21.58 & 31.83 \\
\hline Aromatics & 23.61 & 22.27 & 13.64 & 18.46 & 11.69 & 17.02 \\
\hline Pro + Hyp & 66.65 & 24.03 & 18.38 & 75.03 & 23.63 & 12.34 \\
\hline
\end{tabular}

CF: collagen from fins, HFT: hydrolysate obtained from collagen fins with trypsin, HFP: hydrolysate obtained from collagen fins with protease type XIV, CA: collagen from arms, HAT: hydrolysate obtained from collagen arms with trypsin, HAP: hydrolysate obtained from collagen arms with protease type XIV.

\subsection{Bioactive properties}

Antioxidant activity

DPPH radical scavenging assay is widely used to evaluate the antioxidant capacity of antioxidant compounds. DPPH is a stable radical that shows maximal absorbance at $517 \mathrm{~nm}$ in ethanol (Molyneux, 2004). When the radical is scavenged by accepting an electron or a proton $\left(\mathrm{H}^{+}\right)$from the antioxidant, the radical changes its color from purple to yellow and the absorbance is reduced (Peng et al., 2009). In the present study, collagen hydrolysates are the substances that donate an electron or hydrogen to neutralize the DPPH radical converting it into a stable molecule (Liu et al., 2010). $2.5 \mathrm{mg} / \mathrm{mL}$ of collagen hydrolysates solution was used to measure their radical scavenging activity (RSA) (Figure 2). 
All hydrolysates had higher RSA than unhydrolysed collagen from any squid anatomical region (arms 17.8\% and fins 20.1\%). Hydrolysates produced from jumbo squid arms-derived collagen by both, trypsin and protease XIV exhibited a higher scavenging activity ( 45.1 and $44.2 \%$, respectively) $(p<0.05)$ than those from jumbo squid fins-derived collagen (34.5 and $32.4 \%$ ). Among the proteases evaluated, no differences were detected $(p>0.05)$. The ABTS radical scavenging ability of the collagen was also increased after hydrolysis treatment (Figure 3). The type of by-product as well the type of the enzyme used to obtain the hydrolysates did not affect the ABTS radical scavenging values $(p>0.05)$. The increase in the antioxidant activity of the collagen after hydrolysis is due to the fact that the produced peptides contain electron donors that may react more easily with free radicals converting them into more stable products, which terminates the radical chain reaction (Samaranayaka \& Li-Chan, 2011).

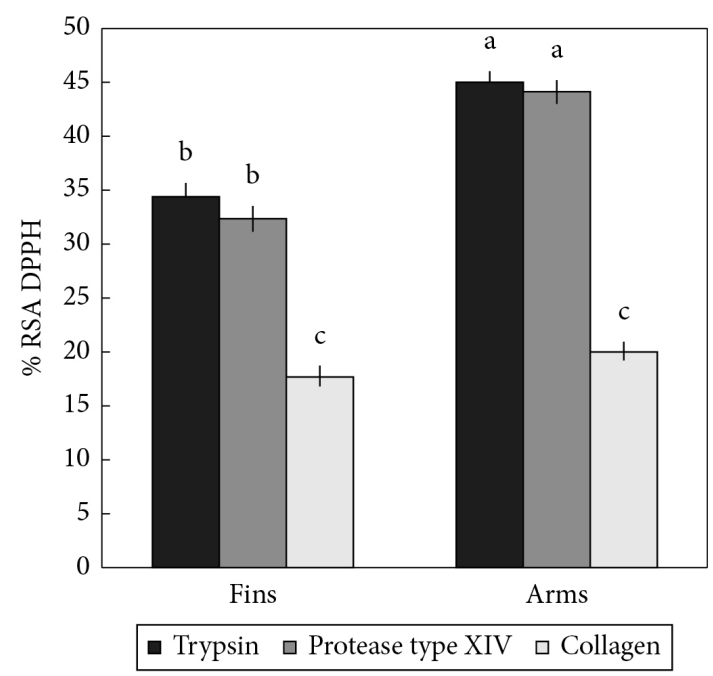

Figure 2. Scavenging activity of radical DPPH of collagen and its hydrolysates. Each value is the mean $\pm \mathrm{SD}$ from triplicate measurements. Values with different letters indicate significant differences $(p<0.05)$.

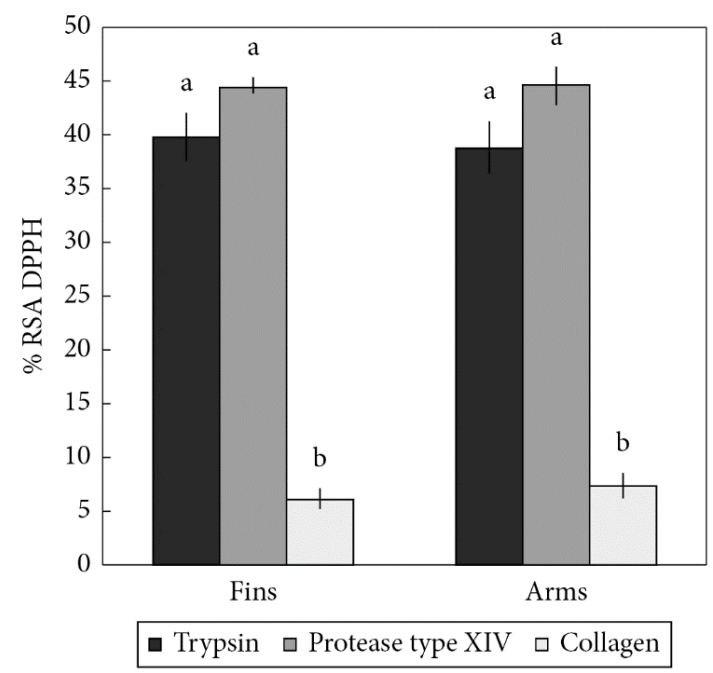

Figure 3. Scavenging activity of radical ABTS of collagen and its hydrolysates. Each value is the mean \pm SD from triplicate measurements. Values with different letters indicate significant differences $(\mathrm{p}<0.05)$.

\section{Antimutagenic activity}

It has been established that antioxidant activity is associated to other biological activities such as antimutagenicity and cell proliferation inhibition (Samaranayaka \& Li-Chan, 2011); therefore, the antimutagenic activity of collagen hydrolysates was determined. HAP was the hydrolysate that most effectively inhibited the mutation induced by $\mathrm{AFB}_{1}$ on both, Salmonella typhimurium strains TA98 and TA100, where a percentage of inhibition higher than $50 \%$ was observed, coinciding with the highest radical scavenging activity (Table 2). This concurs with Alemán et al. (2011b) who found a relationship between bioactive properties and MW distribution of all the hydrolysates; thus, there is a relationship between antioxidant and antimutagenic activities of the obtained hydrolysates.

\section{Antiproliferative activity}

Data presented on Figure 4 show the effect of hydrolysates on the proliferation of murine transformed cells. All the obtained hydrolysates showed low antiproliferative activity (less than $15 \%)$ and no significant $(p>0.05)$ differences were detected between the hydrolysates. The antiproliferative activity of these hydrolysates could be enhanced, using separation techniques in order to concentrate low MW peptides, those considered responsible of biological activities.

Table 2. Effect of different collagen hydrolysates on the mutagenicity induced by AFB1 using Salmonella typhimurium TA98 and Salmonella typhimurium TA100 assay.

\begin{tabular}{ccccc}
\hline & Hydrolysate $^{1)}$ & $\begin{array}{c}\text { Dose } \\
(\mathrm{mg} / \text { plate })\end{array}$ & $\begin{array}{c}\text { Revertants/ } \\
\text { plate }^{2)}\end{array}$ & \% Inhibition \\
\hline TA98 & HFT & 5 & $184.3 \pm 18.1$ & 54.09 \\
& & 0.5 & $209.0 \pm 16.6$ & 47.92 \\
& HFP & 5 & $385.3 \pm 47.0$ & 4.00 \\
& HAT & 5 & $195.3 \pm 15.3$ & 51.32 \\
& & $217.3 \pm 20.5$ & 45.84 \\
& HAP & 5 & $340.0 \pm 14.0$ & 15.28 \\
& & $168.8 \pm 30.2$ & 57.95 \\
TA100 & 0.5 & $216.0 \pm 33.9$ & 46.17 \\
& Negative & & $57.7 \pm 12.9$ & \\
control & & & \\
AFB1 & & $401.3 \pm 17.0$ & \\
HFT & 5 & $191.0 \pm 36.0$ & 76.1 \\
& 0.5 & $240.8 \pm 62.0$ & 69.9 \\
HFP & 5 & $340 \pm 36.4$ & 57.5 \\
& 0.5 & $257.7 \pm 22.7$ & 67.8 \\
HAT & 5 & $224.0 \pm 1.4$ & 72.0 \\
& 0.5 & $206.5 \pm 6.4$ & 74.2 \\
HAP & 5 & $242.5 \pm 54.4$ & 69.7 \\
& 0.5 & $256.3 \pm 45.3$ & 68.0 \\
Negative & & $159.3 \pm 12.6$ & \\
control & & & \\
AFB1 & & $800.0 \pm 8.9$ & \\
\hline
\end{tabular}

${ }^{1)} \mathrm{CF}$ : collagen from fins, HFT: hydrolysate obtained from collagen fins with trypsin, HFP: hydrolysate obtained from collagen fins with protease type XIV, CA: collagen from arms, HAT: hydrolysate obtained from collagen arms with trypsin, HAP: hydrolysate obtained from collagen arms with protease type XIV. ${ }^{2}$ Data presented are the mean $\pm \mathrm{SD}$ of three plates. 


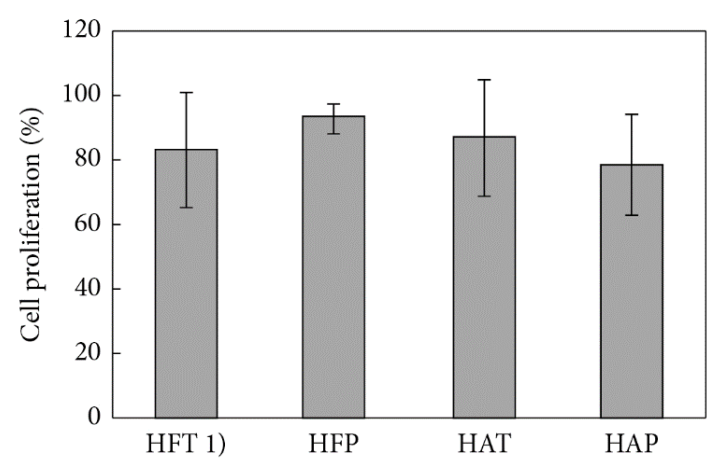

Figure 4. Effect of hydrolysates on cell viability of M12.C3F6 cells. Values are represented as the percent of viable cells with vehicle treated cells regarded as $100 \%$ viable. Results are presented as mean $\pm \operatorname{SD}(n=3)$. 1) HFT: hydrolysate obtained from collagen fins with trypsin, HFP: hydrolysate obtained from collagen fins with protease type XIV, HAT: hydrolysate obtained from collagen arms with trypsin, HAP: hydrolysate obtained from collagen arms with protease type XIV.

\section{Conclusions}

These results demonstrated that squid byproducts such as fins and arms collagen hydrolysates, are capable of acting as antioxidant scavenging radicals; moreover, they exert antimutagenic and antiproliferative properties whereby are susceptible for further studies in order evaluate the biological activities of their components and determine its use as supplement or additive in foods.

\section{Acknowledgements}

This research was supported by CONACYT under grants 154046 and 107102. Suárez-Jiménez was supported by a PhD fellowship granted by CONACYT. The authors are grateful to M.C. María Elena Lugo Sánchez for her technical assistance.

\section{References}

Adler-Nissen, J. (1986). Methods in food protein hydrolysis. In J. AdlerNissen (Ed.), Enzymic hydrolysis of food proteins (pp. 110-169). New York: Elsevier Applied Science Publishers.

Alemán, A., Giménez, B., Montero, P., \& Gómez-Guillén, M. C. (2011a). Antioxidant activity of several marine skin gelatins. LWT - Food Science and Technology, 44(2), 407-413. http://dx.doi.org/10.1016/j. lwt.2010.09.003.

Alemán, A., Pérez-Santín, E., Bordenave-Juchereau, S., Arnaudin, I., Gómez-Guillén, M. C., \& Montero, P. (2011b). Squid gelatin hydrolysates with antihypertensive, anticancer and antioxidant activity. Food Research International, 44(4), 1044-1051. http://dx.doi. org/10.1016/j.foodres.2011.03.010.

Ando, M., Nakagishi, Y., Yoshida, K., Nakao, M., Nakagawa, T., Makinodan, Y., Tsukamasa, Y., \& Kawasaki, K. (2006). Pyridinoline concentrations in muscular and skin collagen of fish and relationship between collagen solubility and pyridinoline concentration in fish muscular collagen. Fisheries Science, 72(5), 1104-1108. http://dx.doi. org/10.1111/j.1444-2906.2006.01262.x.

Burits, M., \& Bucar, F. (2000). Antioxidant activity of Nigella sativa essential oil. Phytotherapy Research, 14(5), 323-328. http://dx.doi.
org/10.1002/1099-1573(200008)14:5<323::AID-PTR621>3.0.CO;2-Q. PMid:10925395.

Foster, J. A. (2013). Elastin. In W. J. Lennarz \& M. D. Lane (Eds.), Encyclopedia of biological chemistry (pp. 192-193). Waltham: Academic Press.

Gildberg, A., Arnesen, J. A., \& Carlehog, M. (2002). Utilisation of cod backbone by biochemical fractionation. Process Biochemistry, 38(4), 475-480. http://dx.doi.org/10.1016/S0032-9592(02)00103-6.

Gómez-Guillén, M. C., Giménez, B., López-Caballero, M. E., \& Montero, M. P. (2011). Functional and bioactive properties of collagen and gelatin from alternative sources: A review. Food Hydrocolloids, 25(8), 1813-1827. http://dx.doi.org/10.1016/j.foodhyd.2011.02.007.

Harnedy, P. A., \& FitzGerald, R. J. (2012). Bioactive peptides from marine processing waste and shellfish: A review. Journal of Functional Foods, 4(1), 6-24. http://dx.doi.org/10.1016/j.jff.2011.09.001.

Je, J. Y., Park, P. J., \& Kim, S. K. (2005). Antioxidant activity of a peptide isolated from Alaska pollack (Theragra chalcogramma) frame protein hydrolysate. Food Research International, 38(1), 45-50. http://dx.doi. org/10.1016/j.foodres.2004.07.005.

Jeon, S. M., Bok, S. H., Jang, M. K., Kim, Y. H., Nam, K. T., Jeong, T. S., Park, Y. B., \& Choi, M. S. (2002). Comparison of antioxidant effects of naringin and probucol in cholesterol-fed rabbits. Clinica Chimica Acta, 317(1-2), 181-190. http://dx.doi.org/10.1016/S00098981(01)00778-1. PMid:11814474.

Kim, S.-K., \& Mendis, E. (2006). Bioactive compounds from marine processing byproducts - A review. Food Research International, 39(4), 383-393. http://dx.doi.org/10.1016/j.foodres.2005.10.010.

Kong, B., \& Xiong, Y. L. L. (2006). Antioxidant activity of zein hydrolysates in a liposome system and the possible mode of action. Journal of Agricultural and Food Chemistry, 54(16), 6059-6068. http://dx.doi. org/10.1021/jf060632q. PMid:16881717.

Kristinsson, H. G. (2007). Functional and bioactive peptides from hydrolyzed aquatic food proteins. In F. Shahidi \& C. Barrow (Eds.), Marine nutraceuticals and functional foods (Nutraceutical Science and Technology, Chap. 9, pp. 229-246). Boca Raton: CRC Press. http://dx.doi.org/10.1201/9781420015812.ch9.

Laemmli, U. K. (1970). Cleavage of structural proteins during the assembly of the head of bacteriophage T4. Nature, 227(5259), 680685. http://dx.doi.org/10.1038/227680a0. PMid:5432063.

Lin, L., \& Li, B. F. (2006). Radical scavenging properties of protein hydrolysates from jumbo flying squid (Dosidicus eschrichitii Steenstrup) skin gelatin. Journal of the Science of Food and Agriculture, 86(14), 2290-2295. http://dx.doi.org/10.1002/jsfa.2600.

Liu, Q., Kong, B., Xiong, Y. L., \& Xia, X. (2010). Antioxidant activity and functional properties of porcine plasma protein hydrolysate as influenced by the degree of hydrolysis. Food Chemistry, 118(2), 403-410. http://dx.doi.org/10.1016/j.foodchem.2009.05.013.

Malaypally, S. P., Liceaga, A. M., Kim, K.-H., Ferruzzi, M., Martin, F. S., \& Goforth, R. R. (2014). Influence of molecular weight on intracellular antioxidant activity of invasive silver carp (Hypophthalmichthys molitrix) protein hydrolysates. Journal of Functional Foods. In press. http://dx.doi.org/10.1016/j.jff.2014.06.011.

Maron, D. M., \& Ames, B. N. (1983). Revised methods for the Salmonella mutagenicity test. Mutation Research, 113(3-4), 173-215. http:// dx.doi.org/10.1016/0165-1161(83)90010-9. PMid:6341825.

Molyneux, P. (2004). The use of the stable free radical diphenylpicrylhydrazyl (DPPH) for estimating antioxidant activity. Songklanakarin Journal of Science and Technology, 26(2), 211-219. 
Morales, J., Montero, P., \& Moral, A. (2000). Isolation and partial characterization of two types of muscle collagen in some cephalopods. Journal of Agricultural and Food Chemistry, 48(6), 2142-2148. http:// dx.doi.org/10.1021/jf990711k. PMid:10888512.

Mosmann, T. (1983). Rapid colorimetric assay for cellular growth and survival: application to proliferation and cytotoxicity assays. Journal of Immunological Methods, 65(1-2), 55-63. http://dx.doi. org/10.1016/0022-1759(83)90303-4. PMid:6606682.

Nielsen, P. M., Petersen, D., \& Dambmann, C. (2001). Improved method for determining food protein degree of hydrolysis. Journal of Food Science, 66(5), 642-646. http://dx.doi.org/10.1111/j.1365-2621.2001. tb04614.x.

Peng, X., Xiong, Y. L., \& Kong, B. (2009). Antioxidant activity of peptide fractions from whey protein hydrolysates as measured by electron spin resonance. Food Chemistry, 113(1), 196-201. http://dx.doi. org/10.1016/j.foodchem.2008.07.068.

Re, R., Pellegrini, N., Proteggente, A., Pannala, A., Yang, M., \& RiceEvans, C. (1999). Antioxidant activity applying an improved ABTS radical cation decolorization assay. Free Radical Biology \& Medicine, 26(9-10), 1231-1237. http://dx.doi.org/10.1016/S0891-5849(98)003153. PMid:10381194.

Samaranayaka, A. G. P., \& Li-Chan, E. C. Y. (2011). Food-derived peptidic antioxidants: a review of their production, assessment, and potential applications. Journal of Functional Foods, 3(4), 229-254. http://dx.doi.org/10.1016/j.jff.2011.05.006.
Sarmadi, B. H., \& Ismail, A. (2010). Antioxidative peptides from food proteins: a review. Peptides, 31(10), 1949-1956. http://dx.doi. org/10.1016/j.peptides.2010.06.020. PMid:20600423.

Schägger, H. (2006). Tricine-SDS-PAGE. Nature Protocols, 1(1), 16-22. http://dx.doi.org/10.1038/nprot.2006.4. PMid:17406207.

Sikorski, Z. E., \& Borderías, J. (1994). Collagen in the muscles and skins of marine animals. In Z. E. Sikorski, B. S. Pan \& F. Shahidi (Eds.), Sea food protein (pp. 58-70). New York: Chapman and Hall.

Torres-Arreola, W., Pacheco-Aguilar, R., Sotelo-Mundo, R. R., RouzaudSandez, O., \& Ezquerra-Brauer, J. M. (2008). Caracterización parcial del colágeno extraído a partir del manto, aleta y tentáculos de calamar gigante (Dosidicus gigas ) partial characterization of collagen from mantle, fin, and arms of jumbo squid (Dosidicus gigas). Ciencia y Tecnologia Alimentaria, 6(2), 101-108. http://dx.doi. org/10.1080/11358120809487634.

Vazquez-Ortiz, F. A., Moron-Fuenmayor, O. E., \& Gonzalez-Mendez, N. F. (2004). Hydroxyproline measurement by HPLC: Improved method of total collagen determination in meat samples. Journal of Liquid Chromatography \& Related Technologies, 27(17), 2771-2780. http://dx.doi.org/10.1081/JLC-200029339.

You, L., Zhao, M., Cui, C., Zhao, H., \& Yang, B. (2009). Effect of degree of hydrolysis on the antioxidant activity of loach (Misgurnus anguillicaudatus) protein hydrolysates. Innovative Food Science \& Emerging Technologies, 10(2), 235-240. http://dx.doi.org/10.1016/j. ifset.2008.08.007. 